\title{
In vitro interactions of fungi associated with anthracnose disease of Musa paradisiaca
}

\author{
Bautista MAC, Gandalera EE and Waing KGD
}

Department of Biological Sciences, College of Science, Central Luzon State University, Science City of Muñoz, Nueva Ecija, Philippines 3120

Bautista MAC, Gandalera EE, Waing KGD 2021 - In-vitro interactions of fungi associated with anthracnose disease of Musa paradisiaca. Plant Pathology \& Quarantine 11(1), 69-82, Doi 10.5943/ppq/11/1/8

\begin{abstract}
Musa paradisiaca Linn. is a common fruit in the Philippines as well as in other countries. If not handled properly, M. paradisiaca fruits could have diseases such as anthracnose. Thus, this study was conducted mainly to isolate fungi present in anthracnose disease of $M$. paradisiaca fruit peels. The isolated fungal species were identified through cultural, morphological and molecular approaches. A total of nine fungal species were identified from the peel of $M$. paradisiaca, infected with anthracnose disease. Using ITS primers, blast analysis revealed that fungal species were identified as Aspergillus flavus (99.47\%), A. niger (97.12\%), A. tamarii (97.47\%), Aureobasidium melanogenum (99.60\%), Cladosporium cladosporioides (99.80\%), Daldinia eschscholzii (98.83\%), Fusarium chlamydosporum (97.50\%), Fusarium sp. (99.60\%) and Penicillium citrinum (99.41\%). In vitro interactions of these identified fungi revealed mutual slight inhibition, mutual inhibition and antagonism. Hyphal denaturation, lysed cells, hyphal coiling and broken hyphae were observed under the microscope. D. eschscholzii can be considered best fungal isolate because it was able to antagonize all other fungal isolates. Therefore, this fungus would be the best candidate to be a biocontrol agent against fungal pathogens to reduce the use of synthetic fungicides.
\end{abstract}

Keywords - biocontrol - fungal organisms - hyphal interaction

\section{Introduction}

In terms of world trade, banana (Musa paradisiaca Linn.) is the fifth most important agricultural food crop and is a prevalent fruit in the world market (Singh et al. 2016). Musa species are used in folk medicine for various treatments and widely distributed in tropical regions (Krishnan et al. 2014). Most of the developing countries population rely on banana as their source of food because of its low cost (Mohapatra et al. 2010). It is one of the oldest cultivated plants, and for the genus Musa of herbaceous plants, its name is ordinary because of the fruit they produce (Kumar et al. 2012). In tradition, the fruits, stems, leaves and roots are used to treat different diseases in human (Imam \& Akter 2011). M. paradisiaca are said to have antihyperglycemic and antimicrobial (Jawla et al. 2012), burn-wound healing (Amutha \& Selvakumari 2014), anthelmintic (Hussain et al. 2011), and antioxidant (Loganayaki et al. 2010) activities.

During transportation and storage, post-harvest diseases cause considerable losses to harvested fruits and vegetables. To control postharvest decay loss, synthetic fungicides are applied. 
However, the use of antagonistic microorganisms of various biological approaches is becoming popular throughout the world because many postharvest diseases can now be controlled by microbial antagonists which is safer and eco-friendly (Sharma et al. 2009). The most important issue for the tropical fruit industry is the management of anthracnose caused by Colletotrichum spp., resulting in financial losses (Maqbool et al. 2011). Another is crown rot, a postharvest disease of $M$. paradisiaca and from the 12 localities in Sri Lanka, there were three isolated crown rot pathogens namely Lasiodiplodia theobromae, Fusarium proliferatum and Colletotrichum musae. These isolated fungal pathogens were able to cause crown rot disease, but the severity of the disease was higher when in a combination of these three virulent pathogens (Anthony et al. 2004).

In the Philippines, banana is a widely known tree and fruit production benefits average economic families and individuals. However, there are post-harvest diseases such as anthracnose in fruit that affect the sales of the market vendors. Thus, this study aimed to determine the fungi associated with anthracnose disease of $M$. paradisiaca peels and the interactions of these isolated fungal species to determine which fungal organism could be used as a possible biological control agent that would lessen the use of synthetic fungicides.

\section{Materials \& Methods}

\section{Collection of samples}

Sampling was done in a banana farm at Villaverde, Nueva Vizcaya and the infected hands of $M$. paradiciaca fruit were gathered for fungal isolation. The fruits were observed until symptoms of anthracnose disease exhibits. The symptoms of anthracnose occur as black or brown blemishes on the peel and different sizes of sunken spots on fruits. The spots may be triangular in shape or angular in edges and may have many salmon-colored fungal acervuli with their associated conidia in the lesions (Nelson 2008).

\section{Isolation of fungal species}

The fungi growing in infected banana peel were isolated by serial dilution. Ten grams of infected $M$. paradisiaca was pulverized using a blender and then mixed with $90 \mathrm{ml}$ sterilized distilled water and was regarded as $10^{-1}$. Six test tubes were prepared to have $9 \mathrm{ml}$ of sterilized distilled water each and were labelled from $10^{-2}$ to $10^{-7}$. From $10^{-1}$ dilution, $1 \mathrm{ml}$ was transferred into $10^{-2}$ dilution. Then, from $10^{-2}$, another $1 \mathrm{ml}$ of sample was transferred to $10^{-3}$. This procedure was repeated up to $10^{-7}$. One $\mathrm{ml}$ of sampling from $10^{-1}, 10^{-3}, 10^{-5}$ and $10^{-7}$ were poured on sterilized petri plate separately. Triplicate was made for each plate. It was incubated at room temperature for 4-5 days or until sufficient mycelial growth was available for isolation.

\section{Cultural characterization of fungal isolates}

Inoculation was done in previously prepared Potato Dextrose Agar (PDA) plates to observe the re-growth, size and pigmentation of the fungal isolates.

\section{Morphological characterization of fungal isolates}

Morphological characterization of isolated fungi were done using the slide culture technique. In a petri plate with moistened tissue paper, a clean glass slide and a coverslip was placed on vshaped foil then sterilized. Agar block approximately $1 \mathrm{~cm}$-thick was placed on the center of the slide. Fungal species was inoculated on the agar block then covered with a sterilized coverslip. The inoculated slides were incubated for 3-5 days at room temperature. After incubation, morphological characteristics such as color of the hypha, shape and color of the spores were observed under a compound microscope. Fungal isolates were identified based on their cultural and morphological characteristics following the manual of Quimio (1988).

\section{Sequence and phylogenetic analysis}

Seven-day old culture of different fungal isolates grown on PDA medium on test tubes was 
sent to the Philippine Genome Center for DNA extraction and sequencing. Phylogeny analysis and tree building were done using the Molecular Evolutionary Genetics Analysis ver 7 (MEGA) (Kumar et al. 2016). Bootstrapping were performed using 1000 replicates. Sequencing were verified by BLAST (Altschul et al. 1990) and aligned Through CLUSTAL W.

\section{In-vitro interaction of identified fungi}

Two different fungi were inoculated using one-point technique at the opposite sides of the plate then allowed to grow for seven days at room temperature. After incubation, colony growth was observed and their interaction was determined.

\section{Identification of In vitro interaction}

Interactions of fungi were described as antagonism and mutual antagonism (Dix \& Webster 1995). Fungal isolates in all antagonism were classified as aggressor or victim. On a broad front, the mycelium of the aggressor overlapped the mycelium of the victim (Dix \& Webster 1995). For mutual antagonism, interaction was classified as either mutual inhibition or mutual slight inhibition. In mutual inhibition, the fungi approached each other until almost each contact, and a narrow demarcation line of more than $2 \mathrm{~mm}$ is visible between the two fungi while mutual slight inhibition has a distance of 0.1 to $2 \mathrm{~mm}$ (Fakhrunnisa et al. 2006).

\section{Interfungal parasitic relationship}

The slide culture technique was done to determine antagonistic interaction between the different fungal species. This procedure was adopted from Matroudi et al. (2009) with minor modifications. In a petri plate with moistened tissue paper, a clean glass slide was placed on vshaped foil then sterilized. The two fungi's inoculum were placed on both ends measuring $1 \mathrm{~cm}$ apart of sterile glass slide separately. The end of the slide was coated with approximately $5.0 \mathrm{~mm}$ thick of PDA while the other end was kept free of the medium to facilitate handling. The inoculated slides were incubated for 3-5 days at room temperature. After incubation, regions, where both hyphae meet, were observed under a compound microscope for the presence of coil formation and penetration structures or wall disintegration.

\section{Results}

A total of 9 species of fungi were isolated and initially identified from banana $(M$. paradisiaca) fruit peel infected with anthracnose disease based on their cultural and morphological characteristics. These were Aspergillus flavus, A. niger, A. tamarii, Aureobasidium melanogenum, Cladosporium cladosporioides, Daldinia eschscholzii, Fusarium chlamydosporum, Fusarium sp., and Penicillium citrinum (Fig. 1). In addition, these identified fungal species underwent DNA extraction and sequencing and the sequences were verified through BLAST (Altschul et al. 1990). Table 1 summarizes the cultural and morphological characteristics of the identified fungi.

\section{Sequence and phylogenetic analysis}

The identities of the fungal organisms isolated from the peel of $M$. paradisiaca infected with anthracnose disease were confirmed through amplification and sequencing of the ITS region using ITS1 and ITS4 primers. BLAST analysis showed the identities of fungal isolates, namely A. flavus, A. niger, A. tamarii, A. melanogenum, C. cladosporioides, D. eschscholzii, F. chlamydosporum, Fusarium sp. and Penicillium citrinum as shown in Table 2. Also, a maximum likelihood tree was constructed based on the ITS1 sequence of the identified fungi as shown on Fig. 2.

The maximum likelihood tree shows the similarity of the cultured fungi against the gathered accessions from the BLAST search conducted using the ITS1 sequence. This phylogenetic analysis serves as a compliment for the morphological identification of the cultured fungi. The bootstrap values observed were between 98-100 which is a high support comparing the sequence of the cultured fungi with the accession and indicates a highly similar identity. Three clades can be seen 
on the phylogenetic tree, wherein the first clade consists of A. tamarii, A. flavus, A. niger, P. citrinum, C. cladosporioides and A. melanogenum. The second clade is composed of Fusarium sp. and $F$. chlamydosporum while the third clade is composed of $D$. escholzii and rooted to the outgroup Hypoxylon fragiforme.

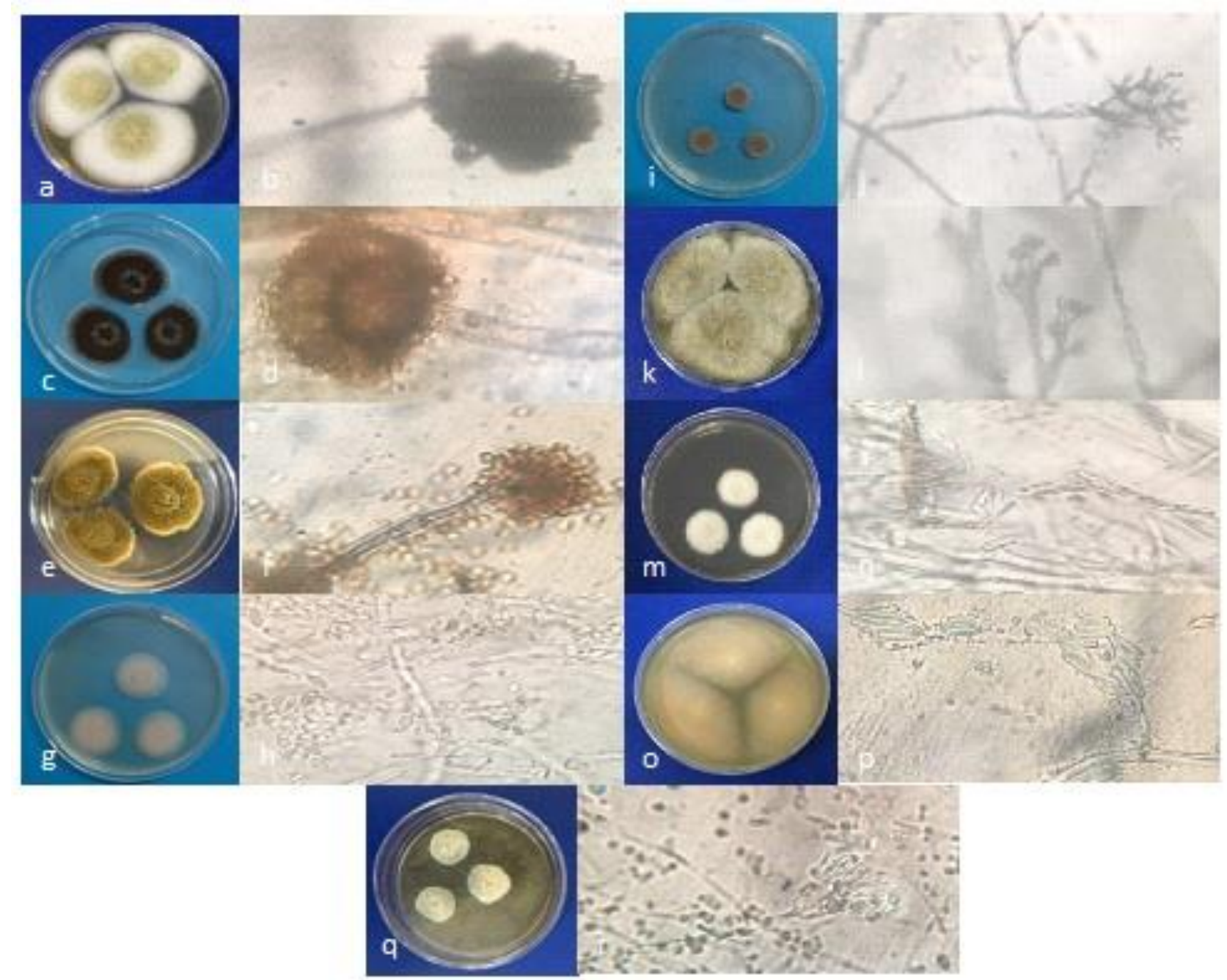

Fig. 1 - Cultural (left) and morphological (right) characteristics of identified fungi. a-b A. flavus. c-d $A$. niger. e-f $A$. tamarii. g-h $A$. tamarii. i-j $C$. cladosporioides. k-1 D. eschscholzii. m-n F. chlamydosporum. o-p Fusarium sp. q-r P. citrinum.

Table 1 Cultural and morphological characteristics of the identified fungi

\begin{tabular}{|c|c|c|c|c|}
\hline \multirow[t]{2}{*}{ Species } & \multicolumn{3}{|c|}{ Cultural Characteristics } & \multirow{2}{*}{$\begin{array}{l}\text { Morphological } \\
\text { Characteristics }\end{array}$} \\
\hline & Obverse side & Reverse side & Size & \\
\hline Aspergillus flavus & $\begin{array}{l}\text { white then powdery } \\
\text { and pale yellow on } \\
\text { the center }\end{array}$ & $\begin{array}{l}\text { white then powdery } \\
\text { and pale yellow on } \\
\text { the center }\end{array}$ & $47.69 \mathrm{~mm}$ & $\begin{array}{l}\text { Rough stipes and } \\
\text { conidia, biseriate } \\
\text { vesicle }\end{array}$ \\
\hline Aspergillus niger & $\begin{array}{l}\text { powdery-like and } \\
\text { black in color with } \\
\text { white halo on its } \\
\text { margin }\end{array}$ & $\begin{array}{l}\text { gray with white } \\
\text { halo on its margin }\end{array}$ & $29.03 \mathrm{~mm}$ & $\begin{array}{l}\text { Globose to } \\
\text { subglobose conidia, } \\
\text { smooth-walled } \\
\text { conidiophores }\end{array}$ \\
\hline Aspergillus tamarii & $\begin{array}{l}\text { yellow-green to } \\
\text { dark green in color } \\
\text { with white on its } \\
\text { margin }\end{array}$ & light yellow-green & $33.13 \mathrm{~mm}$ & $\begin{array}{l}\text { Vesicles and } \\
\text { conidia are } \\
\text { globose, rough } \\
\text { conidiophores }\end{array}$ \\
\hline
\end{tabular}


Table 1 Continued.

\begin{tabular}{|c|c|c|c|c|}
\hline \multirow{2}{*}{ Species } & \multicolumn{3}{|c|}{ Cultural Characteristics } & \multirow{2}{*}{$\begin{array}{l}\text { Morphological } \\
\text { Characteristics }\end{array}$} \\
\hline & Obverse side & Reverse side & Size & \\
\hline $\begin{array}{l}\text { Aureobasidium } \\
\text { melanogenum }\end{array}$ & $\begin{array}{l}\text { dirty white and dry } \\
\text { in appearance }\end{array}$ & $\begin{array}{l}\text { dirty white and dry } \\
\text { in appearance }\end{array}$ & $20.48 \mathrm{~mm}$ & $\begin{array}{l}\text { Thin-walled, } \\
\text { hyaline and smooth } \\
\text { conidia and } \\
\text { conidiophore }\end{array}$ \\
\hline $\begin{array}{l}\text { Cladosporium } \\
\text { cladosporioides }\end{array}$ & grayish brown & black & $12.78 \mathrm{~mm}$ & $\begin{array}{l}\text { Conidia grow at the } \\
\text { top or sides of the } \\
\text { conidiophores and } \\
\text { conidiophores are } \\
\text { branched }\end{array}$ \\
\hline $\begin{array}{l}\text { Daldinia } \\
\text { eschscholzii }\end{array}$ & gray, dense & black & $51.89 \mathrm{~mm}$ & $\begin{array}{l}\text { Rough and } \\
\text { ellipsoid-shaped } \\
\text { conidia, branched } \\
\text { and rough } \\
\text { conidiphores }\end{array}$ \\
\hline $\begin{array}{l}\text { Fusarium } \\
\text { chlamydosporum }\end{array}$ & $\begin{array}{l}\text { white, thick and } \\
\text { cottony raised } \\
\text { mycelial growth }\end{array}$ & light yellow & $22.92 \mathrm{~mm}$ & $\begin{array}{l}\text { Thick-walled, } \\
\text { hyaline, branching } \\
\text { conidiophore- } \\
\text { bearing } \\
\text { microconidia }\end{array}$ \\
\hline Fusarium sp. & light pink & light pink & $45.66 \mathrm{~mm}$ & $\begin{array}{l}\text { Hyaline conidia } \\
\text { and conidiophore }\end{array}$ \\
\hline $\begin{array}{l}\text { Penicillium } \\
\text { citrinum }\end{array}$ & $\begin{array}{l}\text { powdery, green and } \\
\text { light pale yellow } \\
\text { on the center }\end{array}$ & $\begin{array}{l}\text { pale brownish } \\
\text { yellow }\end{array}$ & $16.09 \mathrm{~mm}$ & $\begin{array}{l}\text { Globose and } \\
\text { smooth-walled } \\
\text { conidia is } \\
\text { predominant } \\
\text { symmetrically } \\
\text { verticillate } \\
\text { conidiophores }\end{array}$ \\
\hline
\end{tabular}

Table 2 Identities of the cultured fungi using BLAST with NCBI Genbank Accession

\begin{tabular}{clll}
\hline Isolate No. & \multicolumn{1}{c}{ Species } & \multicolumn{1}{c}{ Identity } & \multicolumn{1}{c}{ Accession } \\
\hline $\mathbf{1}$ & Aspergillus flavus & $99.47 \%$ & MH171489 \\
$\mathbf{2}$ & Aspergillus niger & $97.12 \%$ & MK633877 \\
$\mathbf{3}$ & Aspergillus tamarii & $97.47 \%$ & MH345903 \\
$\mathbf{4}$ & Aureobasidium melanogenum & $99.60 \%$ & MK332446 \\
$\mathbf{5}$ & Cladosporium cladosporioides & $99.80 \%$ & KM103301 \\
$\mathbf{6}$ & Daldinia eschscholzii & $98.83 \%$ & JX139549 \\
$\mathbf{7}$ & Fusarium chlamydosporum & $97.50 \%$ & MK212882 \\
$\mathbf{8}$ & Fusarium sp. & $99.60 \%$ & KF293300 \\
$\mathbf{9}$ & Penicillium citrinum & $99.41 \%$ & MK281570 \\
\hline
\end{tabular}

Looking at the constructed phylogenetic tree, it is seen that both genera of Penicillium and Aspergillus had a bootstrap value of 99 which is a high support. This is primarily because both genera belong to the class Eurotiomycetes, and as members of this group produce saclike structures containing ascospores in either a closed fruiting body. Clade I also show that A. melanogenum and C. cladosporioides diverge earlier from the group depicting a longer evolutionary history as these species belong to the class Dothidiomycetes.

On the other hand, clade II shows the evolutionary relation of the two Fusarium species as they diverge from each other. The node has a 100 bootstrap value indicating a high support. Specifically, Fusarium sp. appeared first than F. chlamydosporum. In addition, these groups belong 
to the class Sordariomycetes wherein they are characterized from having their asci in perithecial fruiting bodies. Lastly, the clade formed by $D$. eschshcolzii and $H$. fragiforme diverges from the rest of the group. Even though that this species also belongs to the class Sordariomycetes it has diverged greatly against with the Fusarium species indicating a short evolutionary history.

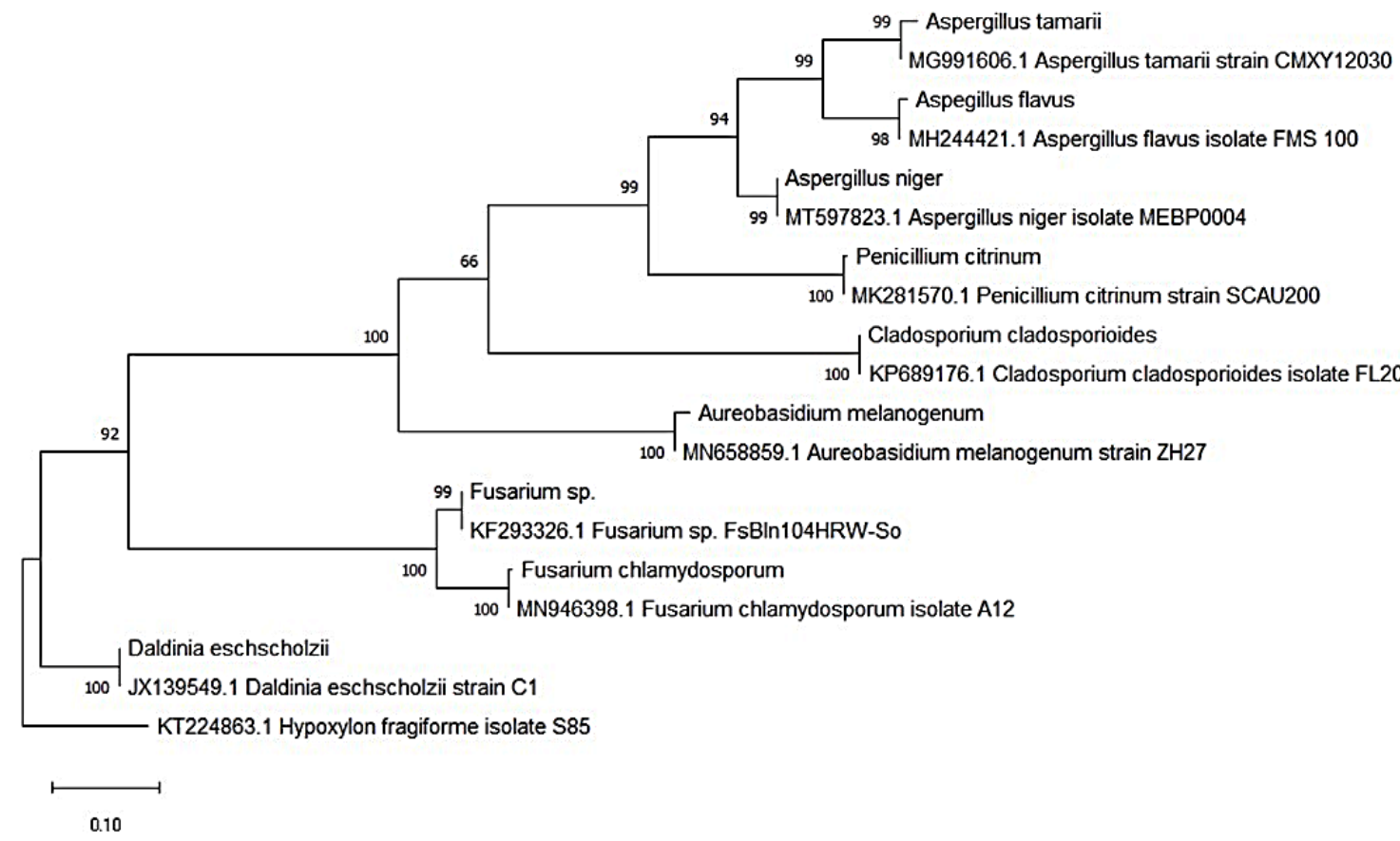

Fig. 2 - Maximum likelihood tree constructed based from the ITS1 region of the cultured fungi.

\section{Test for the interaction among fungal isolates}

Fungal isolates were subjected against each other to determine possible antagonistic interactions (Table 3). The ability to produce growth-inhibiting compounds as well as the ability to infect other fungal species is very important in elucidating fungal properties. Observed fungal interactions include mutual inhibition and slight inhibition, antagonism, hyphal denaturation, hyphal coiling, broken hyphae and lysed cells (Figs 3-7).

Table 3 In vitro interaction of identified fungi

\begin{tabular}{|c|c|c|}
\hline \multicolumn{2}{|c|}{ Interacting Fungi } & \multirow{2}{*}{$\begin{array}{l}\text { Interaction } \\
\text { Antagonism }\end{array}$} \\
\hline A. flavus & A. flavus & \\
\hline A. flavus (+) & A. niger (-) & Antagonism \\
\hline A. flavus (+) & A. tamarii (-) & Antagonism \\
\hline A. flavus (+) & A. melanogenum. (-) & Antagonism \\
\hline A. flavus (+) & C. cladosporioides (-) & Antagonism \\
\hline A. flavus (+) & F. chlamydosporum (-) & Antagonism \\
\hline A. flavus (+) & Fusarium sp. (-) & Antagonism \\
\hline A. flavus (+) & $P$. citrinum $(-)$ & Antagonism \\
\hline A. flavus (-) & D. eschscholzii (+) & Antagonism \\
\hline A. niger (+) & A. tamarii $(+)$ & Mutual slight inhibition \\
\hline A. niger (+) & Fusarium sp. (+) & Mutual slight inhibition \\
\hline A. niger & A. niger & Antagonism \\
\hline A. niger (+) & A. melanogenum (-) & Antagonism \\
\hline A. niger $(+)$ & C. cladosporioides (-) & Antagonism \\
\hline A. niger $(+)$ & F. chlamydosporum (-) & Antagonism \\
\hline A. niger (+) & P. citrinum (-) & Antagonism \\
\hline A. niger (-) & D. eschscholzii (+) & Antagonism \\
\hline
\end{tabular}


Table 3 Continued.

\begin{tabular}{|c|c|c|}
\hline \multicolumn{2}{|c|}{ Interacting Fungi } & \multirow{2}{*}{$\begin{array}{c}\text { Interaction } \\
\text { Mutual slight inhibition }\end{array}$} \\
\hline A. tamarii (+) & P. citrinum $(+)$ & \\
\hline A. tamarii & A. tamarii & Antagonism \\
\hline A. tamarii (+) & A. melanogenum (-) & Antagonism \\
\hline A. tamarii (+) & C. cladosporioides (-) & Antagonism \\
\hline A. tamarii (+) & F. chlamydosporum (-) & Antagonism \\
\hline A. tamarii (+) & Fusarium sp. (-) & Antagonism \\
\hline A. tamarii (-) & D. eschscholzii (-) & Antagonism \\
\hline A. melanogenum (+) & C. cladosporioides $(+)$ & Mutual slight inhibition \\
\hline A. melanogenum (+) & P. citrinum $(+)$ & Mutual inhibition \\
\hline A. melanogenum & A. melanogenum & Antagonism \\
\hline A. melanogenum (-) & D. eschscholzii (+) & Antagonism \\
\hline A. melanogenum (-) & F. chlamydosporum $(+)$ & Antagonism \\
\hline A. melanogenum (-) & Fusarium sp. (+) & Antagonism \\
\hline C. cladosporioides & C. cladosporioides & Mutual slight inhibition \\
\hline C. cladosporioides $(+)$ & P. citrinum $(+)$ & Mutual inhibition \\
\hline C. cladosporioides (-) & D. eschscholzii (+) & Antagonism \\
\hline C. cladosporioides (-) & F. chlamydosporum (+) & Antagonism \\
\hline C. cladosporioides (-) & Fusarium sp. (+) & Antagonism \\
\hline D. eschscholzii & D. eschscholzii & Antagonism \\
\hline D. eschscholzii (+) & F. chlamydosporum & Antagonism \\
\hline D. eschscholzii (+) & Fusarium sp. (+) & Antagonism \\
\hline D. eschscholzii (+) & P. citrinum $(+)$ & Antagonism \\
\hline F. chlamydosporum & F. chlamydosporum & Antagonism \\
\hline F. chlamydosporum $(+)$ & P. citrinum $(-)$ & Antagonism \\
\hline F. chlamydosporum (-) & Fusarium sp. (+) & Antagonism \\
\hline Fusarium sp. & Fusarium sp. & Antagonism \\
\hline Fusarium sp. (+) & P. citrinum (-) & Antagonism \\
\hline (+) aggressor & (-) victim & \\
\hline
\end{tabular}

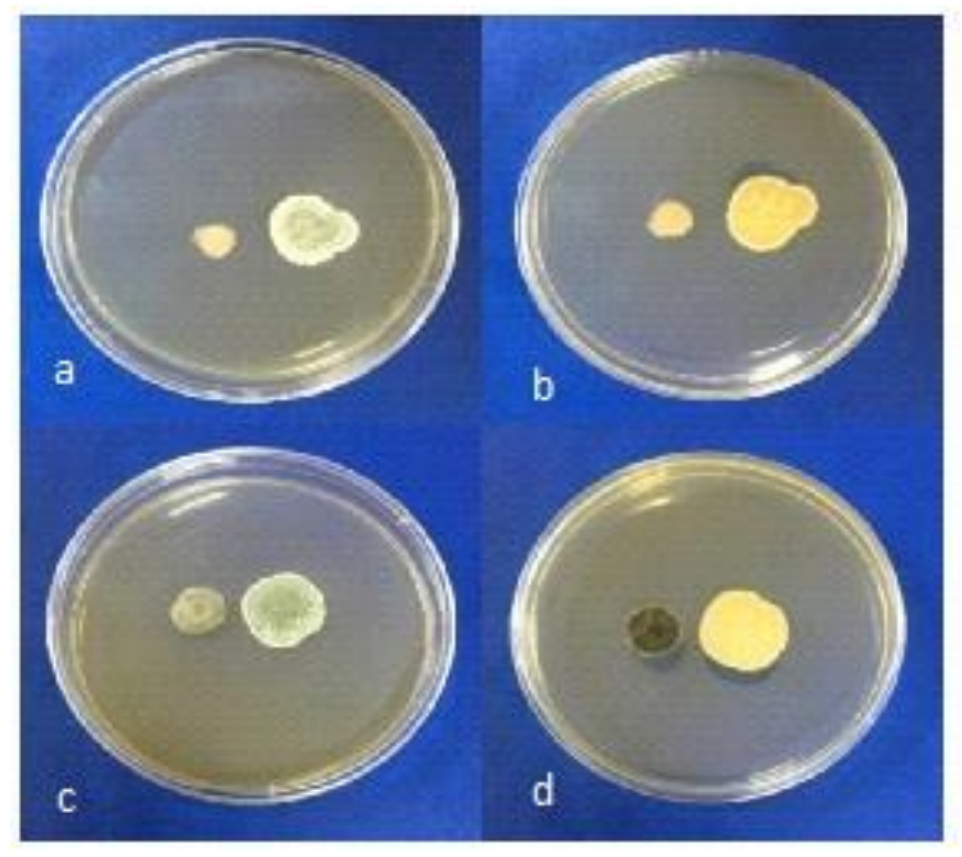

Fig. 3 - Mutual inhibition represented by obverse and reverse side of the fungal plates on the $7^{\text {th }}$ day of incubation. a-b A. melanogenum (left) paired with P. citrinum (right). c-d C. cladosporioides (left) paired with P. citrinum (right). 


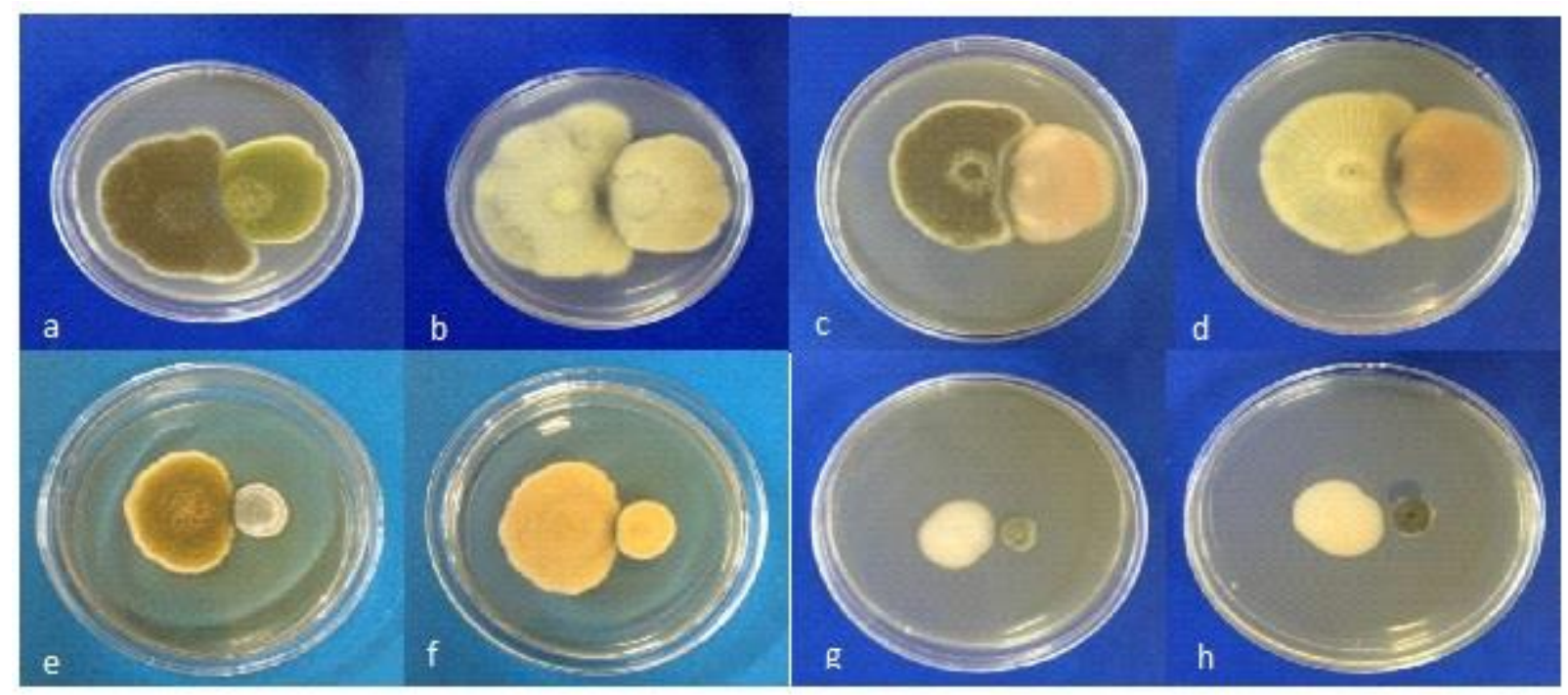

Fig. 4 - Mutual slight inhibition represented by obverse and reverse side of the fungal plates on the $7^{\text {th }}$ day of incubation. a-b A. niger (left) paired with A. tamarii (right). c-d A. niger (left) paired with Fusarium sp. (right). e-f $A$. tamarii (left) paired with $P$. citrinum (right). g-h A. melanogenum (left) paired with $P$. citrinum (right).

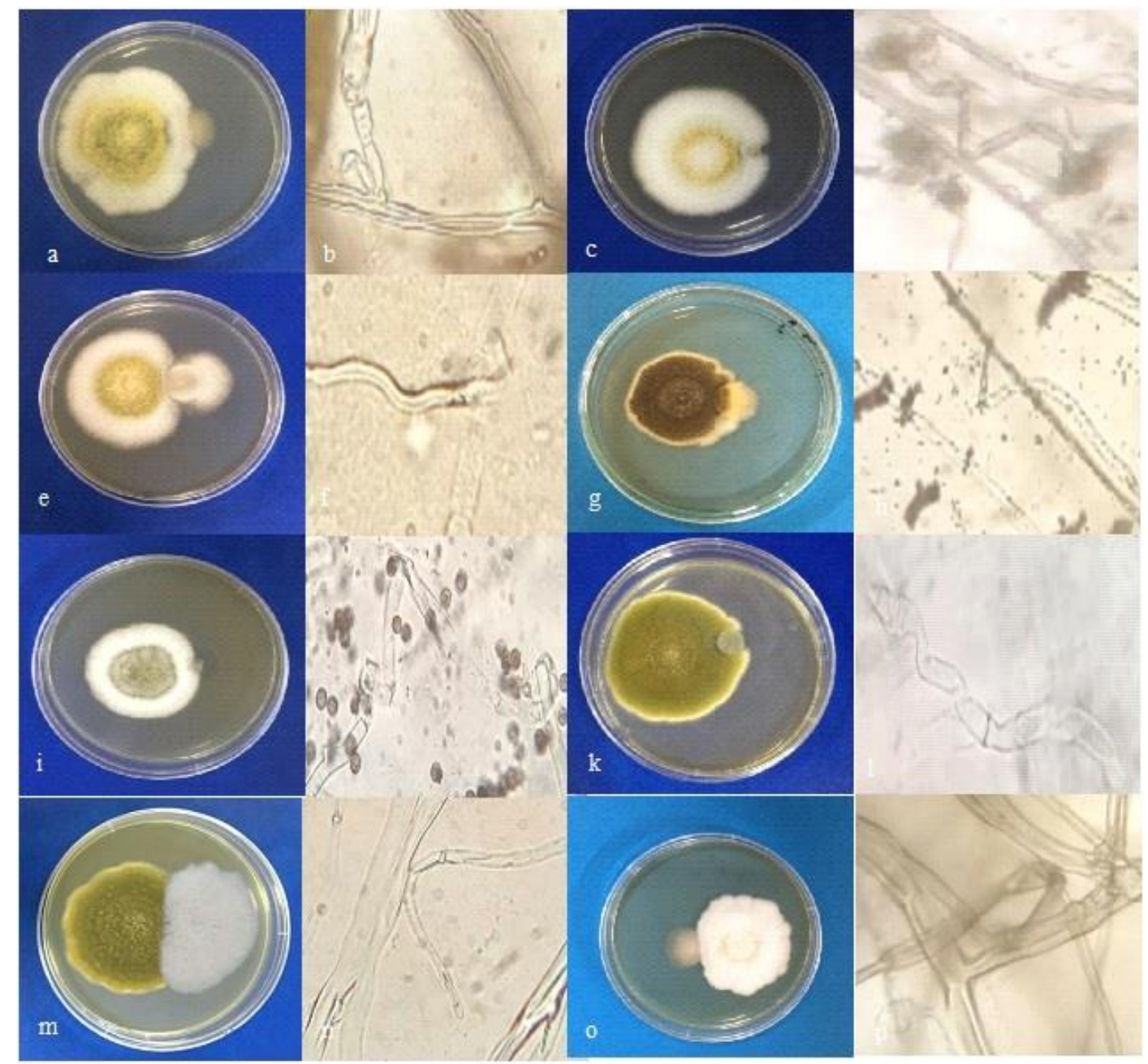

Fig. 5 - Antagonistic interaction of the identified fungal organisms on the $7^{\text {th }}$ day of incubation. a A. flavus (left) and $A$. melanogenum (right). b hyphal denaturation and lysed cells of $A$. melanogenum. c A. flavus (left) and C. Cladosporioides (right). d hyphal denaturation and lysed 
cells of C. cladosporioides. e A. flavus (left) and Fusarium sp. (right). f hyphal denaturation of Fusarium sp. g A. niger (left) and A. melanogenum (right). h hyphal denaturation of $A$. melanogenum. i A. niger (left) and C. cladosporioides (right). j hyphal denaturation and lysed cells of $C$. cladosporioides. k A. tamarii (left) and C. cladosporioides (right). 1 hyphal denaturation of $C$. cladosporioides. m A. tamarii (left) with $F$. chlamydosporum (right). n hyphal denaturation of $F$. chlamydosporum. o A. melanogenum (left) with $F$. chlamydosporum (right). p hyphal denaturation of F. chlamydosporum.

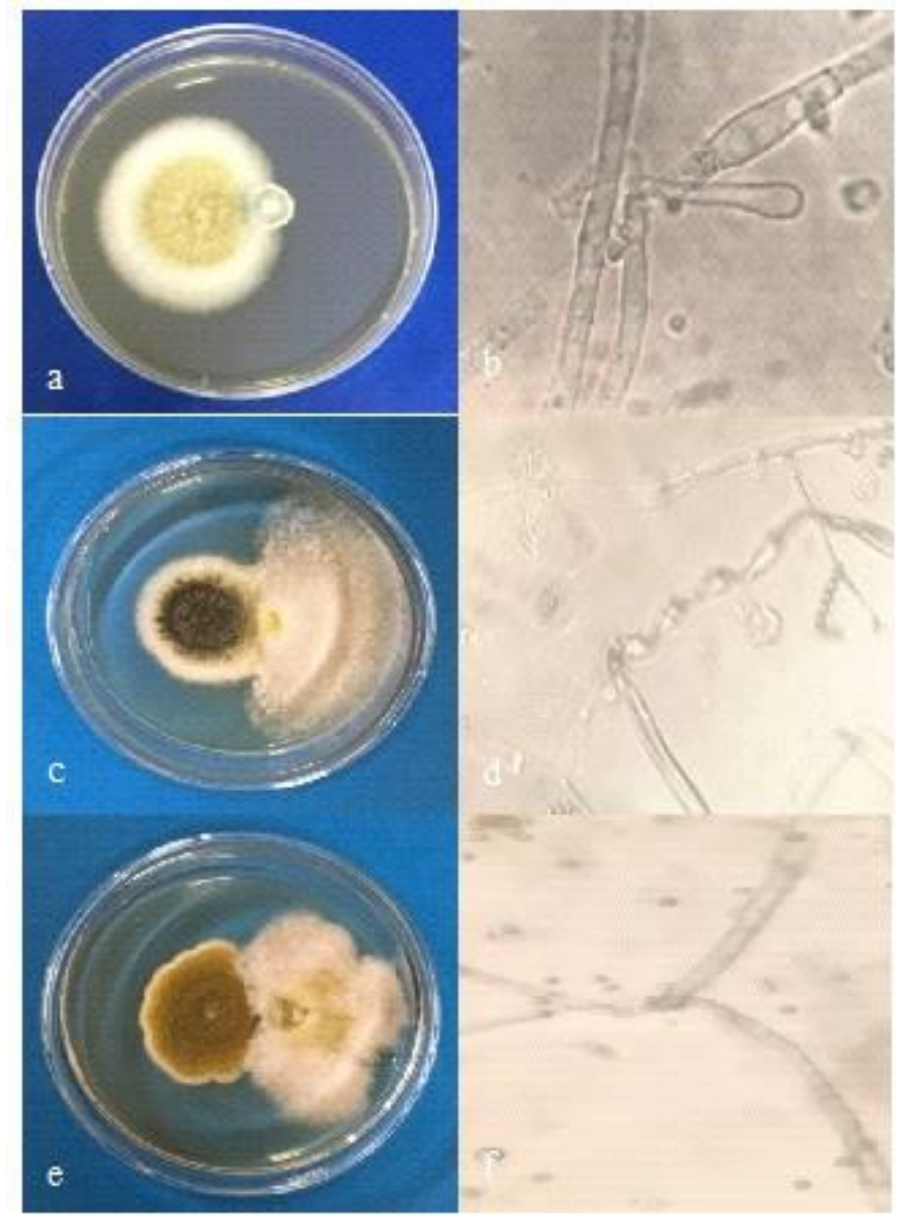

Fig. 6 - Antagonistic interaction of the identified fungal organisms on the $7^{\text {th }}$ day of incubation. a A. flavus (left) with $P$. citrinum (right). b hyphal coiling of $A$. flavus with $P$. citrinum. c A. niger (left) with D. eschscholzii (right). d coiled hyphae of D. eschscholzii with A. niger. e A. tamarii (left) with $D$. eschscholzii (right). f coiled hyphae of $D$. eschscholzii with A. tamarii.
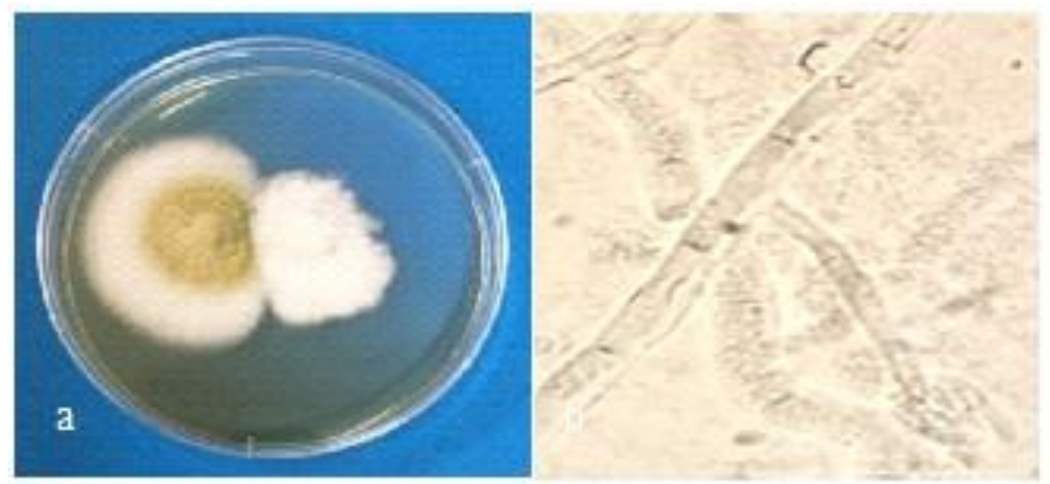

Fig. 7 - Antagonistic interaction on the $7^{\text {th }}$ day of incubation. a A. flavus (left) paired with $F$. chlamydosporum (right). b broken hyphae of $F$. chlamydosporum. 


\section{Discussion}

During storage and ripening of banana, anthracnose develops as one of the post-harvest diseases of fruits (Chillet et al. 2000). Also, Philippine non-chemical bananas' quality problems include lack proper cultural management, careless handling, and poor postharvest practices (Alvindia et al. 2000). In addition, the quality of bananas infected with anthracnose cause economic losses for both producers and traders (Ara et al. 2012). In the case of anthracnose in banana, conidia contaminate the fruits in the field, germinate rapidly and develop an appressorium which hibernates until fruit ripening (Muirhead \& Deverall 1981). Factors that trigger the development of anthracnose in the field are wet, humid and warm weather (Nelson 2008). Moreover, this disease takes place in the period of long transportation and the period of storage with relatively low and high humidity (Thangamani et al. 2011). The main source for the infection is the dispersal of the imperfect fungi Colletotrichum and takes place by rain splash (Hindorf 2000), wind (Madden 1997), transported by insects, or aerial dissemination of ascospores (de Bellaire \& Mourichon 1997). Also, secondary vectors like infected seeds and seedlings contribute to banana peel infection (Hindorf 2000).

Colletotrichum musae is the causative agent of anthracnose disease in banana (Thangamani et al. 2011, Su et al. 2011, Azeem et al. 2016). However, in this research conducted, there were no Colletotrichum species isolated from the peel of banana infected with anthracnose disease. The possible reason would be the presence of other fungi such as Penicillium. Penicillium probably inhibited the growth of $C$. musae. In Kanapathipillai \& Jantan (1985) study, they isolated fungal and bacterial organisms from banana infected with anthracnose. Among the isolates, three species of Penicillium revealed antagonistic activity with varying degrees against $C$. musae. These three Penicillium species were studied for in-vitro and the filtrates of the culture reduced the growth of C. musae using PDA media. In addition, elongation of germ tube and germination of spore of C. musae was inhibited. Also, the production and spread of lesions on the fruits was significantly reduced by one of the Penicillium species.

Epiphytic microorganisms are living suitably in the aerial parts of the plant. The nutrients present on the surfaces affect the growth and activity of the microorganisms (Fokkema 1973). In different communities of microbes, there are number of relationships and interactions. These interactions are characterized as mutualistic to antagonistic and parasitic (Duffy et al. 2003). Mycoparasitism also called hyperparasitism which parasitize the other fungi usually occurs in nature and can lead to hyphal coiling, production of resting body, directed growth of three branches of one of the interacting fungi, formation of appresoria-like structure attached on the hypha, parallel growth of strand of hypha, vacuolation of hypha and collapse of hypha caused by coiling (Dubey \& Dwivedi 1986, Chet et al. 1981). In addition, some key factors of the antagonism of fungi are faster rates of metabolism, anti-microbial metabolites and physiological conformation. Furthermore, biocontrol actions of the fungi, which are the aggressors are mycoparasitism, competition in space and nutrient, antibiosis by secondary metabolites and enzymes and plant defence system induction (Verma et al. 2007). In the study of Barnett \& Binder (1973), there was bursting reaction observed wherein the fungus that antagonised the other obtains nutrients from the dead host cells which may be a necrotrophic type hyperparasitic interaction. Bartnicki-Garcia \& Lippman (1972) stated that by means of interacting a number of different fungi have revealed the same phenomena like increase in vesicle formation and swelling and bursting of hypha which can be dependent upon $\mathrm{pH}$, temperature, ionic strength and character of the bathing solution. These factors could be the reason of the imbalance between cell wall synthesis and cell wall lysis through affecting cell wall synthase and splitting of cell wall enzymes and the release of vesicles comprising autolytic enzymes. Otherwise, the mutual slight inhibition and mutual inhibition are caused by the saprophytes due to the secretion of volatile and non-volatile inhibitors, antibiotics (Dennis \& Webster 1971) and phytoalexins as cited by Pandey et al. (1993). Many saprophytes can influence the pathogens' growth and activity because of the competition in the nutrients (Blakeman \& Fokkema 1982).

The presence of halo suggests antibiosis, which inhibits the growth of microorganism through metabolic products like antibiotics from the interacting microorganism (De Oliveira et al. 2018). 
Antibodies that are toxic to the other microorganisms are connected with the production of secondary metabolites. With antagonistic activity, the production of compounds observed in dual cultures and when zone of inhibition showed. As these metabolites diffuse in the media, the growth either increases or decreases (Schoeman et al. 1999).

Hyphal coiling leads to the disintegration of cells. Also, coiling by means of hocks between the hyphal cells and lysis of cells can lead to the fission in the septa. Moreover, the hypha's penetration to the other after coiling that leads to hyphal cells lysis is because of the enzymatic interactions. The specific fungus penetrates on the inner and directs enzymatic lysis on the protoplasm of the cells on the hypha. The other fungi attacks externally around the other by mycoparasitism. The attacking mode needs first the secretion of lytic enzymes to lyse the hyphal cell wall before lysing the internal cell components. However, lysis of some hyphal cell walls may lead to penetration of the hyphae for nourishment due to the haustoria. In spite of breaking of hyphae, it is because of the secondary metabolites that might be more toxic to the pathogen. Nevertheless, hyphal denaturation can lead to cell lysis (El-Debaiky 2017) and may be due to the production of lytic enzymes and secondary metabolites (Jovicic-Petrovic et al. 2016).

Based on the results obtained, D. eschscholzii revealed antagonistic activity against all the other fungal isolates wherein $D$. eschscholzii was the aggressor, and all the other fungal isolates were the victims. Therefore, D. eschscholzii was considered as the best fungal isolate and could be a candidate to be a biological control agent. Daldinia spp. have been reported to produce volatile organic compounds (VOCs) which can be devoloped in industrial applications for biocontrol and biofuel (Mends et al. 2012, Chan et al. 2015). VOCs exhibit bioactivity against various fungi from diverse phyla (Mends et al. 2012) and assist fungal survival inside the plant (Liarzi et al. 2016). Chan et al. (2015) reported than D. eschscholtzii produces secondary metabolite backbone genes, including lovastatin nonaketide synthase and dimethylally tryptophan synthase (DMATS) and citrinin polyketide synthase. Lovastatin nonaketide synthase is involved in bio-synthesis of lovastatin, a drug that lowers cholesterol (Campbell \& Vederas 2010). In addition, in the synthesis of antibiotic citrinin and ergot alkaloids, dimethylally tryptophan synthase (DMATS) and citrinin polyketide synthase are involved. Ergot alkaloid is said to be toxic to herbivores (Bacetty et al. 2009) while citrinin had antimicrobial activity against pathogens (Shimizu et al. 2005). Daldinia spp. seem to be adapted to survive during the natural environment as well as drought periods. Os-4 orthologue, os-1/nik-1 orthologue, and pbsA orthologue are the gene encoding osmotic stressresponsive proteins present in $D$. eschscholtzii that are involved in the accumulation of osmolytes (Chan et al. 2015). The bigger production of osmolytes induce the development of vegetative structures that is resistant to drought conditions. Furthermore, a new lactone with fungistatic activity against Cladosporium cucumerinum named as helicascolide $\mathrm{C}$ was isolated from $D$. eschscholtzii strain together with helicascolide A (Tarman et al. 2012). Likewise, D. eschscholzii is a well-known fungus due to its ability to produce series of bioactive polyketides like 2,3-dihydro-5hydroxy-2-methylchromen-4-one (TL1-1) as well as immunosuppressive dalesconols A and B (Pan et al. 2015). TL1-1 has been reported to have significant activities including growth inhibitory activity, antifungal activity and cytotoxic activity (Tang et al. 2017). TL1-1 could inhibit the growth of Microbotryum violaceum, a common form of fungal pathogen (Dai et al. 2006). In addition, TL1-1 has also been shown to exhibit antifungal activity against Saccharomyces cerevisiae (Zilla et al. 2013). Moreover, TL1-1 has already been reported to reveal significant cytotoxic activity against the human leukaemia cell line (Gray et al. 1999).

Use of chemical pesticides is the traditional method in protecting the crops from diseases. These fungicides have effects on the consumer and the environment. The polluted atmosphere and damaged environment leave harmful residues, and possibly the development of the resistant strains with repetitive use are perhaps the effects of using chemicals (Naseby et al. 2001). The success in biological control in the upcoming time on the aerial part of the plant will be determined by how useful it is and the absence of harmful effects like mammalian toxicity at the same time with low cost price. Some benefits of biological control include a decrease of long-term damage to the environment by using repetitive use of chemicals and lack of chemical residues on the edible part 
of the crop. There is strong proof that it gives protection against diseases using natural biological control in the field (Blakeman \& Fokkema 1982).

\section{References}

Altschul SF, Gish W, Miller W, Myers, EW, Lipman, DJ. 1990 - Basic local alignment search tool. Journal of Molecular Biology 215, 403-410.

Alvindia DG, Kobayashi T, Yaguchi Y, Natsuaki KT. 2000 - Evaluation of cultural and postharvest practices in relation to fruit quality problems in Philippine non-chemical bananas. Japanese Journal of Tropical Agriculture 44, 178-185.

Amutha K, Selvakumari U. 2014 - Wound healing activity of methanolic stem extract of Musa paradisiaca Linn. (banana) in Wistar albino rats. International Wound Journal 13, 1-5.

Anthony S, Abeywickrama K, Dayananda R, Wijeratnam SW, Arambewela L. 2004 - Fungal pathogens associated with banana fruit in Sri Lanka, and their treatment with essential oils. Mycopathologia 157, 91-97.

Ara I, Rizwana H, Al-Othman MR, Bakir MA. 2012 - Studies of actinomycetes for biological control of Colletotrichum musae pathogen during post harvest anthracnose of banana. African Journal of Microbiology Research 6, 3879-3886.

Azeem M, Shahzad S, Sultana N. 2016 - Prevalence and detection of fungi associated with postharvest rots of banana in Karachi. International Journal of Biology and Biotechnology 13, 587-592.

Bacetty AA, Snook ME, Glenn AE, Noe JP et al. 2009 - Toxicity of endophyte-infected tall fescue alkaloids and grass metabolites on Pratylenchus scribneri. Pytopathoogy 99, 1336-1345.

Barnett HL, Binder FL. 1973 - The fungal host-parasite relationship. Annual Review of Phytopathology 11, 273-292.

Bartnicki-Garcia S, Lippman E. 1972 - The bursting tendency of hyphal tips of fungi: presumptive evidence for a delicate balance between wall synthesis and wall lysis in apical growth . Journal of General Microbiology 73, 487-500.

Blakeman JP, Fokkema NJ. 1982 - Potential for biological control of plant diseases on the phylloplane. Annual Review of Pytopathology 20, 167-190.

Campbell CD, Vederas JC. 2010 - Biosynthesis of lovastatin and related metabolites formed by fungal iterative PKS enzymes. Biopolymers 93, 755-763.

Chan CL, Yew SM, Ngeow Y, Na S et al. 2015 - Genome analysis of Daldinia eschscholtzii strains UM 1400 and UM 1020, wood-decaying fungi isolated from human hosts. BMC Genomics $16,1-14$.

Chet I, Harman GE, Baker R. 1981 - Trichoderma hamatum: its hyphal interactions with Rhizoctonia solani and Pythium spp. Microbial Ecology 7, 29-38.

Chillet M, de Bellaire LD, Dorel M, Joas J et al. 2000 - Evidence for the variation in susceptibility of bananas to wound anthracnose due to Colletotrichum musae and the infuence of edaphic conditions. Scientia Horticulturae 86, 33-47.

Dai J, Krohn K, Florke U, Draeger S et al. 2006 - Metabolites from the endophytic fungus Nodulisporium sp. from Juniperus cedre. Journal of Organic Chemistry 15, 3498-3506.

de Bellaire LD, Mourichon X. 1997 - The pattern of fungal contamination of the banana bunch during its development and potential influence on incidence of crown-rot and anthracnose diseases . Plant Pathology 46, 481-489.

Dennis BC, Webster J. 1971 - Antagonistic properties of species-groups of Trichoderma. Transactions of the British Mycological Society 57, 25-39.

Dix NJ, Webster J. 1995 - Fungal ecology. London. Chapman \& Hall.

De Oliveira CF, Moura PF, Rech KS, De Oliveira CS et al. 2018 - Antagonistic activity of Diplodia pinea against phytopathogenic fungi. Folia Microbiologica 64(3), 415-419.

Dubey RC, Dwivedi RS. 1986 - Desctructive mycoparasitic behaviour of Fusarium solani (Mart.) App. and Woll. against Mucor spinosus Van Tieghem. Microbios Letter 32, 123-127. 
Duffy B, Schouten A, Raajimakers JM. 2003 - Pathogen self-defense: mechanisms to counteract microbial antagonism. Annual Review of Pytopathology 41, 501-538.

El-Debaiky SA. 2017 - Antagonistic studies and hyphal interactions of the new antagonist Aspergillus piperis against some pytopathogenic fungi in-vitro in comparison with Trichoderma harzianum. Microbial Pathogenesis 113, 135-143.

Fakhrunnisa M, Hashmi H, Ghaffar A. 2006 - In vitro interaction of Fusarium spp., with other fungi. Pakistan Journal of Botany 38(4), 1317-1322.

Fokkema NJ. 1973 - The role of saprophytic fungi in antagonism against Drechslera sorokiniana (Helminthosporium sativum) on agar plates and on rye leaves with pollen. Physiological Plant Pathology 3, 195-205.

Gray LE, Gardner HW, Weisleder D, Leib M. 1999 - Production and toxicity of 2,3dihydro-5hydroxy-2-methyl-4H-1-benzopyran-4-one by Phialophora gregata. Phytochemistry 50, $1337-1340$.

Hindorf H. 2000 - Colletotrichum spp. causing anthracnose to tropical crops. Acto Horticulturae $531,275-282$.

Hussain A, Khan MN, Iqbal Z, Sajid MS, Khan MK. 2011 - Anthelmintic activity of Trianthema portulacastrum L. and Musa paradisiaca L. against gastrointestinal nematodes of sheep. Veterinary Parasitology 179, 92-99.

Imam M, Akter S. 2011 - Musa paradisiaca L. and Musa sapientum L.: a phytochemical and pharmacological review. Journal of Applied Pharmaceutical Science 1, 14-20.

Jawla S, Kumar Y, Khan M. 2012 - Antimicrobial and antihyperglycemic activities of Musa paradisiaca flowers. Asian Pacific Journal of Tropical Biomedicine 2, 914-918.

Jovicic-Petrovic J, Jeremic S, Vuckovic I, Vojnovic S et al. 2016 - Aspergillus piperis A/5 from plum-distilling waste compost produces. Archives of Biological Sciences 68, 279-289.

Kanapathipillai VS, Jantan R. 1985 - Approach to Biological Control of Anthracnose Fruit Rot of Bananas. Universiti Pertanian Malaysia (pp. 4-6). Serdang: EPrints 3.

Krishnan SC, Subramanian IP, Subramanian SP. 2014 - Isolation, characterization of syringin, phenylpropanoid glycoside from Musa paradisiaca tepal extracta and evaluation of its antidiabetic effect in streptozotocin-induced diabetic rats. Biomedicinie and Preventive Nutrition 4, 105-111.

Kumar KP, Bhowmik D, Duraivel S, Umadevi M. 2012 - Traditional and medicinal uses of banana. Journal of Pharmacognosy and Phytochemistry 1, 57-70.

Kumar S, Stecher G, Tamura K. 2016 - MEGA7: Molecular evolutionary genetics analysisi virsion 7.0 for bigger datasets. Molecular Biology and Evolution 33, 1870-1874.

Liarzi O, Bar E, Lewinsohn E, Ezra D. 2016 - Use of the endophytic fungus Daldinia cf. concentrica and its volatiles as bio-control agents. PLOS One 11, 1-18.

Loganayaki N, Rajendrakumaran D, Manian S. 2010 - Antioxidant capacity and phenolic content of different solvent extracts from banana (Musa paradisiaca) and mustai (Rivea hypocrateriformis). Food Science and Biotechnology 9, 1251-1258.

Madden LV. 1997 - Effects of rain on splash dispersal of fungal pathogens. Canadian Journal of Plant Pathogen 19, 225-230.

Maqbool M, Ali A, Alderson PG, Mohamed MT et al. 2011 - Postharvest application of gum arabic and essential oils for controlling anthracnose and quality of banana and papaya during cold storage. Postharvest Biology and Technology 62, 71-76.

Matroudi S, Zamani MR, Motallebi M. 2009 - Antagonistic effects of three species of Trichoderma sp. on Sclerotinia sclerotiorum, the causal agent of canola stem rot. Egyptian Journal of Biology 11(1), 37-44.

Mends TM, Yu E, Strobel GA, Hassan SR et al. 2012 - An endophytic Nodulisporium sp. producing volatile organic compounds having bioactivity and fuel potential. Journal of Petroleum and Environmental Biotechnology 3, 1-7.

Mohapatra D, Mishra S, Sutar N. 2010 - Banana and its by-product utilisation: an overview. Journal of Scientific and Industrial Research 69, 323-329. 
Muirhead IF, Deverall BJ. 1981 - Role of appressoria in latent infection of banana fruits by Colletotrichum musae. Physiological Plant Pathology 19, 77-84.

Nelson S. 2008 - Postharvest rots of banana. Plant Diseases 1-4.

Naseby DC, Pascual JA, Lynch JM. 2001 - Effect of biocontrol strains of Trichoderma on plant growth, Pythium ultimum populations, soil microbial communities and soil enzyme activities. Journal of Applied Microbiology 88, 161-169.

Pan ZH, Jiao RH, Lu YH, Tan RX. 2015 - Enhancement of dalesconols A and B production via upregulation of laccase activity by medium optimization and inducer supplementation in submerged fermentation of Daldinia eschscholzii. Bioresource Technology 192, 346-353.

Pandey RR, Arora DK, Dubey RC. 1993 - Antagonistic interactions between fungal pathogens and phylloplane fungi of guava. Mycopathologia 124, 31-39.

Quimio TH. 1988 - Illustrated Philippine Fungi, Laguna, Philippines: University of the Philippines - Los Baños.

Schoeman MW, Webber JF, Dickinson DJ. 1999 - The development of ideas in biological control applied to forest products. International Biodeterioraton and Biodegradation 43, 109-123.

Sharma RR, Singh D, Singh R. 2009 - Biological control of postharvest diseases of fruits and vegetables by microbial antagonists: a review. Biological Control 50, 205-221.

Shimizu T, Kinoshita H, Ishihara S, Sakai K et al. 2005 - Polyketide synthase gene responsible for citrinin biosynthesis in Monascus purpureus. Applied and Environmental Microbiology 71, 3453-3457.

Singh B, Singh JP, Amritpal K, Singh N. 2016 - Bioactive compounds in banana and their associated health benefits - a review. Food Chemistry 206, 1-11.

Su YY, Noireung P, Liu F, Hyde KD et al. 2011 - Epitypification of Colletotrichum musae, the causative agent of banana anthracnose. Mycoscience 52, 376-382.

Tang L, Wei X, An F, Lu Y. 2017 - Preparative separation of TL1-1 from Daldinia eschscholzii extract by macroporous resin and evaluation of its antimicrobial activities. Journal of Chromatography B 1060, 22-29.

Tarman K, Palm GJ, Porzel A, Merzweiler K et al. 2012 - Helicascolide C, a new lactone from an Indonesian marine algicolous strain of Daldinia eschscholzii (Xylariaceae, Ascomycota). Phytochemistry Letters 5, 83-86.

Thangamani PR, Kuppusamy P, Peeran MF, Gandhi K, Raguchander T. 2011 - Morphological and physiological characterization of Colletotrichum musae the causal organism of banana anthracnose. World Journal of Agricultural Sciences 7, 743-754.

Verma M, Brar SK, Tyagi RD, Surampalli RY, Valero JR. 2007 - Antagonistic fungi, Trichoderma spp.: panoply of biological control. Biochemical Engineering Journal 37, 1-20.

Zilla MK, Qadri M, Pathania AS, Strobel GA et al. 2013 - Bioactive metabolites from an endophytic Cryptosporiopsis sp. inhabiting Clidemia hirta. Phytochemistry 95, 291-297. 